Original Article

\title{
LANNEA BARTERI ENGL. (ANACARDIACEAE) PLANT USED IN THE TREATMENT OF URINARY TRACT INFECTIONS IN IVORY COAST: BIOLOGICAL AND CHEMICAL STUDIES OF THE AQUEOUS EXTRACT
}

\author{
BREDOU JEAN BRICE ${ }^{1}$, BOUA BOUA BENSON ${ }^{*}$, KONAN KOUADIO FERNIQUE ${ }^{2}$, KABRAN GUY ROGER MIDA ${ }^{1}$, \\ KOUASSI KOUADIO CHRISTIAN ${ }^{1}$, GUESSENND KOUADIO NATHALIE ${ }^{2}$, MAMYRBEKOVA BEKRO JANAT \\ AKHANOVNA ${ }^{1}$, BEKRO YVES ALAIN ${ }^{1}$
}

${ }^{1}$ Laboratoire de Chimie Bio-Organique et de Substances Naturelles (LCBOSN/www.lablcbosn.com), UFR-SFA, Université Nangui Abrogoua, 02 BP 801 Abidjan 02 (République de Côte d'Ivoire), 'Laboratoire de Bactériologie-Virologie Institut Pasteur de Côte d'Ivoire, 01 BP490 Abidjan 01 Email: bouayao@yahoo.fr

Received: 02 Aug 2018 Revised and Accepted: 13 Nov 2018

ABSTRAC'T

Objective: This research aims to evaluate the antibacterial activity and determine the chemical composition of the aqueous extract of the bark of Lannea barteri Engl. (DA) used in the traditional treatment of urinary tract infections in the Ivory Coast.

Methods: The material is composed of DA, the bacterial strains of Pseudomonas aeruginosa and Acinetobacter baumannii, isolated from the urine of patients from different hospitals and subsequently stored. The qualitative analysis was performed using color-based detection tests and thin layer chromatography (TLC) reactions and the quantification of total phenols, flavonoids, flavone aglycones and anthocyanins using the method of Folin Ciocalteu. The method of diffusion on Mueller Hinton (MH) agar medium has been used for sensitivity tests.

Results: The phytochemical screening of DA has revealed the presence of polyphenols, terpenes, and derivatives, coumarins, tannins, flavonoids, and alkaloids. Furthermore, the quantification of some polyphenols such as flavonoids, flavone aglycones, and anthocyanins was determined. The total polyphenols found was $0.757 \pm 0.003 \mathrm{mg} / \mathrm{g}$ MS representing respectively; $0.230 \pm 0.01$ for flavonoids; $0.028 \pm 0.02$ for flavone aglycones and $0.016 \pm 0.02 \mathrm{mg} / \mathrm{g}$ MS for anthocyanins. DA is bactericidal against Pseudomonas aeruginosa and Acinetobacter baumannii, which are mainly responsible for urinary tract infections.

Conclusion: The bark of Lannea barteri Engl. (DA) is rich in flavonoids, flavone aglycones, and anthocyanins which are probably responsible for its antibacterial properties on Pseudomonas aeruginosa and Acinetobacter baumannii. This research thereby supports the use of this plant in the treatment of urinary tract infections.

Keywords: Lannea barteri engl., Pseudomonas aeruginosa, Acinetobacter baumannii, Ivory Coast

(c) 2018 The Authors. Published by Innovare Academic Sciences Pvt Ltd. This is an open-access article under the CC BY license (http://creativecommons.org/licenses/by/4.0/J DOI: http://dx.doi.org/10.22159/ijpps.2018v10i12.28920

\section{INTRODUCTION}

Nosocomial infections are currently a major public health problem in some developing countries. In Ivory Coast, the prevalence is estimated at about $12 \%$ [1]. These infections are partly due to hygienic conditions in the hospitals. Thus, this situation promotes the proliferation of different kinds of bacteria such as Pseudomonas aeruginosa and Acinetobacter baumannii. Because of their high resistance to antibiotics, these bacteria are mostly responsible for the transmission of many hospital pathologies including urinary tract infections [2-6]. This multidrug-resistant antibiotic limits all possible therapeutic choices, leading to an increase in the morbidity and mortality rate [2]

From this fact, the search for new bioactive molecules appears to be essential through other treatment methods such as traditional medicine. Lannea barteri Engl. was chosen for this work, it is a dioeciously tree of the family Anarcadiaceae, used in traditional Ivorian medicine to treat various conditions, including urinary tract infections. The studies carried out on this plant have reported its antimicrobial, antibacterial and antifungal properties [7]. However, these results remain insufficient for an efficient evaluation of Lannea barteri Engl. Thus, this research is a contribution to the valorization of Ivory Coast flora and especially of Lannea barteri Engl. through phytochemical and biological studies on multi-resistant strains.

\section{MATERIALS AND METHODS}

Chemical study

Plant material

The plant material consists essentially of the bark of Lannea barter Engl. (Anarcadiaceae). These barks come from ethnobotanical surveys carried out among traditional healers and herbalists in various markets of Abobo and Adjamé in the autonomous district of Abidjan (Southern Ivory Coast). Firstly we have identified the plant sample at the National Center of Floristic (CNF) located at University Felix Houphouet Boigny (Abidjan, Cocody). A voucher specimen was deposited in the Herbarium (UCJ 000 967). Secondly, the barks were harvested in the month of April 2017 in Brofodoumé, the town of the city of Alépé (Southern Ivory Coast). The organs were cleaned, dried under permanent air conditioning at $18{ }^{\circ} \mathrm{C}$ for $14 \mathrm{~d}$, then pulverized using an electric grinder (NASCO type electric grinder (Model No: UBC-25) to give fine powders.

\section{Preparation of the decoction}

$100 \mathrm{~g}$ of fine powder was dissolved in $1000 \mathrm{ml}$ of distilled water in an Erlenmeyer flask. The flask was surmounted by an ascending condenser and boiled for $30 \mathrm{~min}$. After filtration under vacuum, the filtrate was concentrated using a rotary evaporator and then dried in an oven at $50^{\circ} \mathrm{C}$ for $2 \mathrm{~d}$ to give the aqueous decoction of Lannea barteri Engl. (DA).

Qualitative analysis

The qualitative analysis was performed using color-based detection tests and thin layer chromatography (TLC) reactions [8-11]. The development (mobile phase) used consists of the following solvent system: toluene/ethyl acetate/acetic acid (9.7/3/0.3, v/v/v) used by adding 2 drops of ammonia. The reagents of Liebermann-Bürchard Dragendorff, Neu, $5 \%$ lead (II) acetate and 2\% iron (III) chloride were used to reveal and characterize the main classes of chemical compounds. 


\section{Quantitative analysis}

The quantification of total phenols, flavonoids, flavone aglycones, and anthocyanins was performed by spectrophotometry, using respectively the methods of Folin Ciocalteu [10], Hariri et al. (1991) and Lebreton et al. (1967) [11].

\section{Antibacterial activities}

\section{Biological material}

The biological material is composed of bacterial strains provided by the Laboratory of Bacteriology-Virology, Unit of Antibiotics, Natural Substances and Monitoring of Microorganisms Resistance to Anti-
Infective (ASSURMI) of the Pasteur Institute, Ivory Coast. The strains were essentially those of Pseudomonas aeruginosa and Acinetobacter baumannii isolated from the urine of patients from different hospitals and subsequently stored. The codes and phenotypes are shown in table 1.

\section{Sterility test of the extract da}

$0.1 \mathrm{~g}$ of the aqueous extract (DA) were tested by adding $10 \mathrm{ml}$ of thioglycolate in Petri dishes then incubated at $37^{\circ} \mathrm{C}$ for $24 \mathrm{~h}$. The mixture was inoculated into some Petri dishes containing Mueller Hinton agar (MH) and incubated under the same conditions. DA is thereby declared sterile if no colony is found or detected in the different agar plates after $72 \mathrm{~h} \mathrm{[12]}$.

Table 1: Code and phenotype of bacterial strains

\begin{tabular}{|c|c|c|}
\hline Bacterial strains & Code & Phenotype \\
\hline Pseudomonas & 19UB/17CNRa & Wild phenotypes with carbapenems, fluoroquinolones; cephalosporinases of the low resistance level \\
\hline \multirow[t]{4}{*}{ aeruginosa } & 151PP/17CNRa & Wild phenotype with aminoacids; \\
\hline & & $\begin{array}{l}\text { Penicillinase of the high level of resistance; } \\
\text { cephalosporinases of the low resistance level }\end{array}$ \\
\hline & 316UB/17CNRa & Wild phenotype of cephalosporine \\
\hline & & Crossed resistances of fluoroquinolone \\
\hline \multirow[t]{3}{*}{$\begin{array}{l}\text { Acinetobacter } \\
\text { baumannii }\end{array}$} & 45LC/17CNRa & $\begin{array}{l}\text { Wild phenotypes with aminoacids, carbapenems; cephalosporinases of low resistance level and } \\
\text { Penicillinase of low level }\end{array}$ \\
\hline & 248UB/17CNRa & Carbapenems; Penicillinase; Cephalosporinases; crossed resistance to ticarcillin and piperacillin \\
\hline & 354UB/17CNRa & Resistance to fluoroquinones and Cephalosporinases \\
\hline
\end{tabular}

\section{Preparation of the concentration range of da}

The bacterial strains of Pseudomonas aeruginosa and Acinetobacter baumannii were grown in Petri dishes containing nutrient agar. After $18 \mathrm{~h}$ of incubation at $37^{\circ} \mathrm{C}$, bacterial suspensions were taken using a platinum loop; homogenized in $10 \mathrm{ml}$ of Mueller-Hinton Broth (BMH) and incubated for $3 \mathrm{~h}$ at $37^{\circ} \mathrm{C} .0 .1 \mathrm{ml}$ of the opalescent pre-culture broth was removed and diluted with $10 \mathrm{ml}$ of BMH. The bacterial suspension obtained made it possible to have about 106 $\mathrm{CFU} / \mathrm{ml}$ (standard condition), which constituted the bacterial dilution inoculum 100 or the pure inoculum [13].

\section{Enumeration of the bacterial inoculum}

The bacterial inoculum was homogenized and then diluted from 10 to 10 till $10^{-4}$ to obtain four decimal dilutions of $10^{-1}$ to $10^{-4}$. The initial bacterial inoculum and the four dilutions were inoculated with a loop calibrated at $2 \mu \mathrm{l}$ in $5 \mathrm{~cm}$ long streak on an $\mathrm{MH}$ agar, then incubated for $24 \mathrm{~h}$ at $37^{\circ} \mathrm{C}$. This preparation was labeled as box A which will be used to determine the minimum bactericidal concentration (MBC) [14].

Preparation of the concentration range of the extract (DA)

An initial solution $(100 \mathrm{mg} / \mathrm{ml})$ of DA was prepared. From the stock solution, a series of double dilution in geometrical progression of ratio $1 / 2$ was performed to obtain five concentration ranges $(100 ; 50$; $25 ; 12.5$ and $6.25 \mathrm{mg} / \mathrm{ml}$ ) [14].

\section{Antibacterial test}

The antibacterial tests were carried out according to the dilution method in a liquid medium in six experimental tubes including a control tube $[15,16] .1 .8 \mathrm{ml}$ of the bacterial inoculum was distributed to all tubes. $0.2 \mathrm{ml}$ of the different DA concentrations were dispensed into the different tubes starting from the lowest to the highest concentration except for the control tube which received only $0.2 \mathrm{ml}$ of sterile distilled water. The contents of the transparent tubes (not cloudy) were inoculated by streak $5 \mathrm{~cm}$ long on the $\mathrm{MH}$ agar starting with the MIC tube and incubated at $37{ }^{\circ} \mathrm{C}$ under $\mathrm{CO}_{2}$ $(10 \%)$ for $24 \mathrm{~h}$. This box constituted the box B. The minimum bactericidal concentration was determined by comparing the density of streaks of box B to that of box A previously prepared.

\section{Statistical analyzes}

All assays were performed in triplicate; a spectrophotometer (AL800/SPECTER DIRECT) was used for the determination of the inhibition diameters and antibacterial parameters (MIC and MBC) as well. The statistical analysis of all the data was computed using Microsoft Office Excel.

\section{RESULTS AND DISCUSSION}

\section{Chemical study}

\section{Qualitative analysis}

With an extractive value of $7.75 \%$, the study of the chemical composition of the aqueous extract of Lannea barteri Engl. bark (DA) performing the detection tests by color reactions indicated the presence of several secondary metabolites (table 1, fig. 2). Among which, we count polyphenols, flavonoids, tannins, coumarins, alkaloids, terpenes, and derivatives. In addition, the presence of these phyto-compounds was confirmed by thin layer chromatography (TLC) (fig. 1 and table 3). Indeed, the flavonoids are colored in yellow after the spots revelation using Neu's reagent, in red, fluorescent yellow and blue under UV/366 $\mathrm{nm}$ [17]. These are the following retardation factor ratios $(\mathrm{Rf})$ : $\mathrm{Rf}=0.18 ; 0.26 ; 0.33$; $0.38 ; 0.46 ; 0.54$.

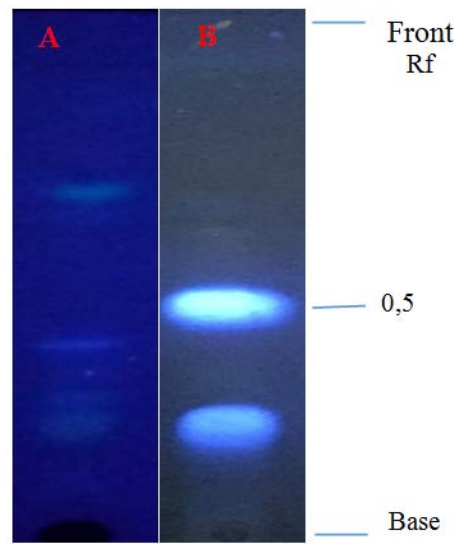

Fig. 1: TLC Chromatography fingerprints of DA extract

In addition, some flavonoids appear in blue under UV/366 nm without any revelation, and the color of these spots intensified after 
spraying the reagent of $\mathrm{Neu}$; they have been identified as methylated flavonoids: $\mathrm{Rf}=0.26$ [8]. Coumarins are detected by the lead (II) acetate in fluorescent blue, violet, yellow with $\mathrm{Rf}=0.1 ; 0.26 ; 0.31$; 0.4. The reagent of Liebermann Bürchard made it possible to highlight on the one hand sterols with $\mathrm{Rf}=0.13 ; 0.15 ; 0.2 ; 0.69 ; 0.8$ in brown and green in the visible and in yellow and yellow-green under UV at $366 \mathrm{~nm}$ [18-19]. On the other hand, the terpenes are detected at $\mathrm{Rf}=0.1 ; 0.69 ; 0.8$ in blue and violet in the visible and yellow-orange under UV/366 nm [17]. Finally, the tannins and alkaloids were identified respectively with iron trichloride in gray or black with Rf $=; 0.0 ; 0.32 ; 0.51 ; 0.55$ and with Dragendorff's reagent in a yellow spot at $\mathrm{Rf}=0.0$ [8].

The aqueous decoction of the bark of Lannea barteri Engl. (DA) was analyzed in 3 replicates $(n=3)$ and identical $R f$ was obtained after comparison. Fig. 1A: Solvent system (Developing); Toluene/ethyl acetate/acetic acid +2 drops of ammonia (9.7/3/0.3; v/v/v), visualized in the visible. Fig. 1B: Developing; Toluene/ethyl acetate/acetic acid +2 drops of ammonia (9.7/3/0.3; v/v/v), Developer (revealer): NEU and visualized at UV $366 \mathrm{~nm}$.

Table 2: Phytocompounds detected in DA extract by colored test

\begin{tabular}{lll}
\hline Type of compound & Test & Observed color \\
\hline Polyphenols & $\mathrm{FeCl}_{3}$ & Black \\
Flavonoïds & Shinoda, & Orangey-red \\
& Lead acetate & Yellow \\
Coumarins & Lactone cycle & Yellow \\
Tannins & $\mathrm{FeCl}_{3} \mathrm{Bromine} \mathrm{water}$ & Black \\
Sterols and polyterpenes & $\mathrm{CH}_{3} \mathrm{CO}_{3} \mathrm{CH}_{3} / \mathrm{H}_{2} \mathrm{SO}_{4}$ & Purple-blue \\
Alkaloïds & Dragendorff & Orangey-red (crystal deposit) \\
\hline
\end{tabular}

The tests were repeated 3 times $(n=3)$ to ensure accuracy and reproducibility,+indicates positive reactions (presence of compound).

Table 3: Secondary metabolites detected by thin-layer chromatography (TLC) in DA

\begin{tabular}{|c|c|c|c|c|c|c|c|c|c|c|c|c|c|c|c|c|c|c|c|c|c|c|c|c|c|}
\hline \multirow{4}{*}{$\begin{array}{l}E \\
X \\
T\end{array}$} & \multicolumn{4}{|c|}{$\begin{array}{l}\text { Without } \\
\text { revealing (a) }\end{array}$} & \multicolumn{4}{|c|}{$\mathrm{FeCl}_{3}$ (b) } & \multicolumn{4}{|c|}{ NEU (c) } & \multicolumn{4}{|c|}{$\begin{array}{l}\text { Libermann-Büchard } \\
\text { (d) }\end{array}$} & \multicolumn{4}{|c|}{ Lead acetate (e) } & \multicolumn{4}{|c|}{ Dragendorff (f) } & \multirow{4}{*}{$\begin{array}{l}\text { Type of } \\
\text { possible } \\
\text { compounds }\end{array}$} \\
\hline & \multicolumn{2}{|c|}{$\begin{array}{l}\text { Visibl } \\
\text { e }\end{array}$} & \multicolumn{2}{|c|}{ UV 366} & \multicolumn{2}{|c|}{ Visible } & \multicolumn{2}{|c|}{$\begin{array}{l}U V \\
366\end{array}$} & \multicolumn{2}{|c|}{$\begin{array}{l}\text { Visibl } \\
\text { e }\end{array}$} & \multicolumn{2}{|c|}{ UV 366} & \multicolumn{2}{|c|}{ Visible } & \multicolumn{2}{|c|}{ UV 366} & \multicolumn{2}{|c|}{$\begin{array}{l}\text { Visibl } \\
\text { e }\end{array}$} & UV & & Visi & & $\begin{array}{l}\text { UV } \\
366\end{array}$ & & \\
\hline & C & $\mathbf{R}$ & Co & $\mathbf{R}_{\mathrm{f}}$ & $\mathbf{C}$ & $\mathbf{R}$ & C & $\mathbf{R}$ & C & $\mathbf{R}$ & Co & $\mathbf{R}_{\mathrm{f}}$ & Co & $\mathbf{R}_{\mathbf{f}}$ & Co & $\mathbf{R}_{\mathbf{f}}$ & C & $\mathbf{R}$ & Co & $\mathbf{R}_{\mathbf{f}}$ & Co & $\mathbf{R}$ & $\mathrm{C}$ & $\mathbf{R}$ & \\
\hline & o & f & & & o & f & $\mathbf{o}$ & f & $\mathbf{o}$ & $f$ & & & & & & & o & f & & & & f & o & f & \\
\hline $\mathbf{D}$ & & & & & $\mathrm{Gr}$ & 0 & & & & & & & & & & & & & & & Ora & 0 & & & Tannins (b), \\
\hline A & & & & & is & & & & & & & & & & & & & & & & nge & & & & alkaloïds $s^{(f)}$ \\
\hline & & & & & & & & & & & & & & & Blu & 0. & & & Gre & 0. & & & & & Coum $(\mathrm{e})$,terpene( \\
\hline & & & & & & & & & & & & & & & e & 1 & & & en & 1 & & & & & d) \\
\hline & & & & & & & & & & & & & Gr & 0. & & & & & & & & & & & sterols (d) \\
\hline & & & & & & & & & & & & & ay & 13 & & & & & & & & & & & \\
\hline & & & & & & & & & & & & & & & $\begin{array}{l}\text { Yell } \\
\text { ow }\end{array}$ & $\begin{array}{l}0 . \\
15\end{array}$ & & & & & & & & & $\begin{array}{l}\text { Sterols (d) } \\
\text { terpenes }(\mathrm{d})\end{array}$ \\
\hline & & & & & & & & & & & Ora & 0. & & & & & & & & & & & & & Flavonoïds (c) \\
\hline & & & & & & & & & & & nge & 18 & & & & & & & & & & & & & \\
\hline & & & & & & & & & & & & & $\mathrm{Gr}$ & 0. & & & & & & & & & & & sterols (d) \\
\hline & & & $\mathrm{PI}$ & 0 & & & & & & & Plu & 0 & & 2 & $\mathrm{Pl}_{4}$ & 0 & & & $C_{n}$ & & & & & & \\
\hline & & & $\begin{array}{l}\text { D1 } \\
\text { ue }\end{array}$ & $\begin{array}{l}0 . \\
26\end{array}$ & & & & & & & Blue & $\begin{array}{l}0 . \\
26\end{array}$ & & & $\begin{array}{l}\text { Blu } \\
\text { e }\end{array}$ & $\begin{array}{l}0 . \\
26\end{array}$ & & & $\begin{array}{l}\text { Gre } \\
\text { en }\end{array}$ & $\begin{array}{l}0 . \\
26\end{array}$ & & & & & $\begin{array}{l}\text { Flavonoids } \\
(\mathrm{a}, \mathrm{c}) \text { coumarins (e) }\end{array}$ \\
\hline & & & $\mathrm{Bl}$ & 0. & & & & & & & & & & & & & & & Gre & 0. & & & & & Coumarins (e) \\
\hline & & & ue & 31 & & & & & & & & & & & & & & & en & 31 & & & & & \\
\hline & & & & & $\mathrm{Gr}$ & 0. & & & & & & & & & & & & & & & & & & & tanins (b) \\
\hline & & & & & ay & 32 & & & & & & & & & & & & & & & & & & & \\
\hline & & & & & & & & & & & Gre & 0. & & & & & & & & & & & & & Flavonoïds (c) \\
\hline & & & & & & & & & & & en & 33 & & & & & & & & & & & & & \\
\hline & & & & & & & & & & & Pur & 0. & & & & & & & & & & & & & $\mathrm{NI}$ \\
\hline & & & & & & & & & & & ple & 37 & & & & & & & & & & & & & \\
\hline & & & & & & & & & & & Blue & $\begin{array}{l}0 . \\
38\end{array}$ & & & & & & & & & & & & & Flavonoïds (c) \\
\hline & & & $\mathrm{Bl}$ & 0. & & & & & & & & & & & & & & & Blu & 0. & & & & & Coumarins (e) \\
\hline & & & ue & 4 & & & & & & & & & & & & & & & $\mathrm{e}$ & 4 & & & & & \\
\hline & & & & & & & & & & & Ora & 0. & & & & & & & & & & & & & Flavonoïds (c) \\
\hline & & & & & & & & & & & nge & 46 & & & & & & & & & & & & & \\
\hline & & & & & $\mathrm{Gr}$ & 0. & & & & & & & & & & & & & & & & & & & tanins (b) \\
\hline & & & & & ay & 51 & & & & & & & & & & & & & & & & & & & \\
\hline & & & & & & & & & & & Ora & 0. & & & & & & & & & & & & & Flavonoïds (c) \\
\hline & & & & & & & & & & & nge & 54 & & & & & & & & & & & & & \\
\hline & & & & & $\mathrm{Gr}$ & 0. & & & & & & & & & & & & & & & & & & & $\operatorname{tanins}(\mathrm{b})$ \\
\hline & & & & & ay & 55 & & & & & & & & & & & & & & & & & & & \\
\hline & & & & & & & & & & & & & & & Yell & 0. & & & & & & & & & Sterols (d); \\
\hline & & & & & & & & & & & & & & & ow & 69 & & & & & & & & & terpenes(d) \\
\hline & & & & & & & & & & & & & & & Yell & 0. & & & & & & & & & Sterols (d) \\
\hline & & & & & & & & & & & & & & & ow & 8 & & & & & & & & & terpenes ${ }^{(d)}$ \\
\hline
\end{tabular}

DA: Aqueous extract; Co: Colour; $\mathrm{R}_{\mathrm{f} .:}$ Retardation factor; NI: Not identified; Coum: Coumarins; $\mathrm{n}=3$

\section{Quantitative analysis}

Fig. 2 describes the amount of different phenolic compounds embedded in Lannea barteri Engl. The results highlight that the overall polyphenols content is $0.757 \pm 0.03 \mathrm{mg} \mathrm{AG} / \mathrm{g} \mathrm{DM}$ and the number of total flavonoids is found to be $0.230 \pm 0.01 \mathrm{mg} / \mathrm{g}$ DM representing $30.38 \%$. Furthermore, flavone aglycones and anthocyanins were found with respective amounts of $0.028 \pm 0.02 \mathrm{mg} / \mathrm{g} \mathrm{DM}$ and $0.016 \pm 0.02 \mathrm{mg} / \mathrm{g} \mathrm{DM}$. The 
obtained results are clear indications of the richness of the studied extracts in different classes of flavonoids.

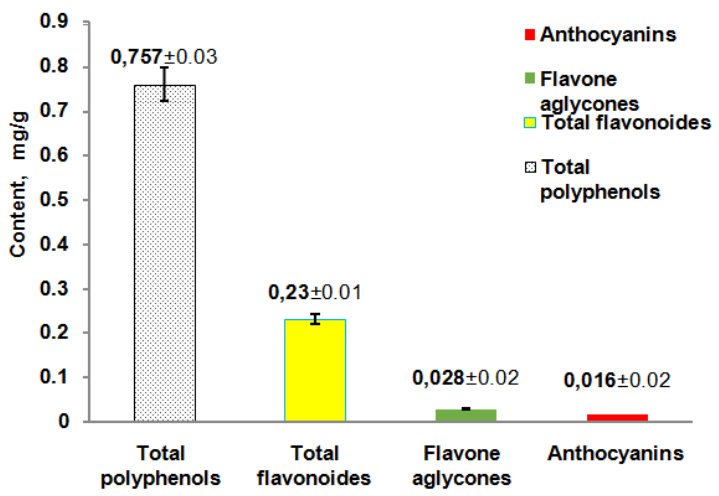

Fig. 2: Content of total phenols and flavonoids, flavones aglycones, anthocyanins extracts of Lannea barteri Engl. (DA), values are expressed as mean $\pm S D, n=3$
The pharmacological potentials of the same extracts were investigated performing specific antibacterial tests, and the obtained results are thereafter described.

\begin{abstract}
Antibacterial test
According to the sterility tests, no evidence of DA contamination was observed as attested by the absence of bacterial colonies on the different agar plates, after $24 \mathrm{~h}$. Table 4 fully describes the results of the sensitivity of Pseudomonas aeruginosa and Acinetobacter baumannii to DA extracts. The inhibition diameters recorded for Pseudomonas aeruginosa strains vary from $11.7 \pm 0.5$ to $15.3 \pm 1.1$ and from $7 \pm 1.0$ to $14 \pm 0.6$ for 100 , and $50 \mathrm{mg} / \mathrm{ml}$ of $\mathrm{DA}$ applied. Concerning the strains of Acinetobacter baumannii, the obtained inhibition diameters are between $10.6 \pm 0.5$ and $15 \pm 0.0$ for the concentration of $100 \mathrm{mg} / \mathrm{ml}$ and $7 \pm 1.7$ and $12.6 \pm 0.0$ for $50 \mathrm{mg} / \mathrm{ml}$. Finally, for the concentration of $25 \mathrm{mg} / \mathrm{ml}$, the inhibition diameters observed are all equal to $6 \pm 0.0$ upon all the studied strains. Additionally, the antibiotics gave some inhibition diameters comprised between $6 \pm 0.0$ and $34 \pm 0.7$. The inhibition zones were greater than $8 \mathrm{~mm}$; it was then appropriate to calculate and determine the antibacterial parameters (MBC and MIC) and their ratio MBC/MIC (table 5, fig. 3)
\end{abstract}

Table 4: Inhibition zone (in $\mathrm{mm}$ ) of the bacterial strains used

\begin{tabular}{|c|c|c|c|c|c|c|c|}
\hline \multirow[t]{2}{*}{ Bacterial strains } & \multirow[t]{2}{*}{ Code } & \multicolumn{4}{|c|}{ Concentration ( $\mathrm{C}$ in $\mathrm{mg} / \mathrm{ml} \pm \mathrm{SD}$ ) } & \multicolumn{2}{|c|}{ Antibiotics } \\
\hline & & $\begin{array}{l}C_{1} \\
(100)\end{array}$ & $\begin{array}{l}C_{2} \\
(50)\end{array}$ & $\begin{array}{l}C_{3} \\
(25)\end{array}$ & Tm & $\begin{array}{l}\text { CAZ } \\
(10 \mu \mathrm{g})\end{array}$ & $\begin{array}{l}\text { TIC } \\
(75 \mu \mathrm{g})\end{array}$ \\
\hline \multirow[t]{3}{*}{ Pseudomonas aeruginosa } & 19UB/17CNRa & $11.7 \pm 0.5$ & $8 \pm 1.0$ & $6 \pm 0.0$ & $6 \pm 0.0$ & $26 \pm 1.4$ & $15 \pm 0.7$ \\
\hline & 151PI/17CNRa & $15.3 \pm 1.1$ & $14 \pm 0.6$ & $6 \pm 0.0$ & $6 \pm 0.0$ & $33 \pm 1.4$ & $23 \pm 2.8$ \\
\hline & 316UB/1CNRa & $14.3 \pm 0.5$ & $7 \pm 1.0$ & $6 \pm 0.0$ & $6 \pm 0.0$ & $30 \pm 2.8$ & $18 \pm 0.7$ \\
\hline \multirow[t]{3}{*}{ Acinetobacter baumannii } & 45LC/17CNRa & $15 \pm 0.0$ & $12.6 \pm 0$ & $6 \pm 0.0$ & $6 \pm 0.0$ & $22.6 \pm 0.5$ & $28.3 \pm 1.3$ \\
\hline & 248UB/17CNRa & $13.3 \pm 1.5$ & $7 \pm 1.7$ & $6 \pm 0.0$ & $6 \pm 0.0$ & $34 \pm 0.7$ & $21 \pm 2.1$ \\
\hline & 354UB/17CNRa & $10.6 \pm 0.5$ & $8 \pm 1.0$ & $6 \pm 0.0$ & $6 \pm 0.0$ & $23 \pm 0.4$ & $6 \pm 0.0$ \\
\hline
\end{tabular}

CAZ: Ceftazidime; TIC: Ticarcilline; Tm: control; values are expressed as mean \pm SD, $n=3$

Table 5: Influence of DA and antibacterial parameters; MIC, MBC, MIC/MBC

\begin{tabular}{|c|c|c|c|c|c|}
\hline Bacterial strains & Code & MIC (mg/ml) & MBC (mg/ml) & (MIC/MBC) & Activity \\
\hline \multirow{3}{*}{ Pseudomonas aeruginosa } & 19UB/17CNRa & $6.25 \pm 0.0$ & $6.25 \pm 0.0$ & 1 & absolute bactericidal \\
\hline & 151PI/17CNRa & $21.87 \pm 6.2$ & $21.87 \pm 6.2$ & 1 & absolute bactericidal \\
\hline & 316UB/17CNRa & $25 \pm 17.6$ & $25 \pm 17.6$ & 1 & absolute bactericidal \\
\hline \multirow[t]{3}{*}{ Acinetobacter baumannii } & 45LC/17CNRa & $43.75 \pm 1.2$ & $43.75 \pm 1.2$ & 1 & absolute bactericidal \\
\hline & 248UB/17CNRa & $34.37 \pm 18.7$ & $34.37 \pm 18.7$ & 1 & absolute bactericidal \\
\hline & 354UB/17CNRa & $25 \pm 0.0$ & $25 \pm 0.0$ & 1 & absolute bactericidal \\
\hline
\end{tabular}

MIC: Minimum Inhibitory Concentration, MBC: Minimum Bactericidal Concentration, Tests were performed 3 times $(\mathrm{n}=3)$ and the concentrations expressed as mean $\pm \mathrm{SD}$.

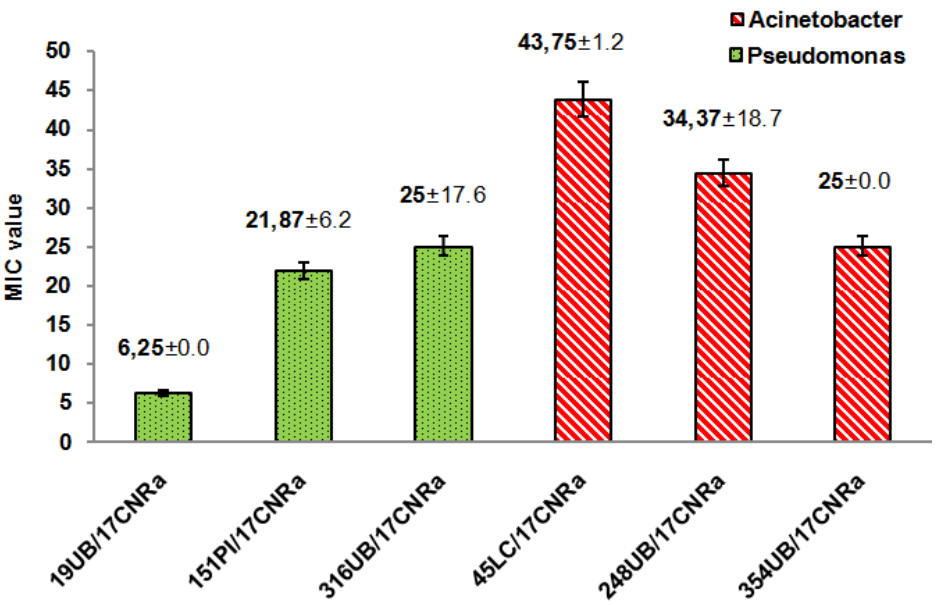

Fig. 3: MIC value of bacterial strains, all the experiments were triplicated, and the results plotted as mean \pm SD 


\section{DISCUSSION}

The phytochemical screening identified the presence of sterols, terpenes, alkaloids, tannins, coumarins, and flavonoids in the extracts of Lannea barteri Engl. (DA). These results are similar to those obtained by Kone and his research team in 2011 working on the same species acclimated in Ivory Coast [7]. As highlighted by the quantitative analyses; a significant amount of total polyphenols (0.757 mg AG/g DM) was found in DA, these phenolic compounds are main classes of flavonoids as mentioned above with probable presence of coumarins and tannins in the extracts. Comparing these results with those of Kone et al. who found $0.25446 \mathrm{mg} \mathrm{AG/g} \mathrm{MS} \mathrm{[7],}$ it appears that the species acclimated in the locality of Alépé (South of Ivory Coast) is richer in polyphenols than the one of Ferkessedougou (northern Ivory Coast). This may be justified by the vegetation, climate and soil types which are important factors in the distribution and content of secondary metabolites in plant species [20]. The amounts of total flavonoids and flavonol aglycones are respectively $0.230 \mathrm{mg} / \mathrm{g} \mathrm{DM}$ and $0.028 \mathrm{mg} / \mathrm{g} \mathrm{DM}$; the values reflect the abundance of flavonoids in Lannea barteri Engl.

Antibacterial tests have demonstrated the sensitivity of the tested strains to DA as a gradual increase in the inhibition zone was noticed with increasing concentrations of the extracts. It comes out that the diameters of inhibition obtained using $100 \mathrm{mg} / \mathrm{ml}$ are greater than the limiting diameter $(10 \mathrm{~mm})$, we can, therefore, affirm that DA is efficient at this concentration of $100 \mathrm{mg} / \mathrm{ml}$ [21]. This is an indication of its effectiveness on Pseudomonas aeruginosa and Acinetobacter baumannii. Indeed, according to Ponce et al. (2003), a bacteria is said to be resistant to an extract when the inhibition diameter induced by this extract is less than $8 \mathrm{~mm}$. An extract is considered effective if it is able to induce some inhibition diameters comprised between 9 and $14 \mathrm{~mm}$. For diameter between 15 to $19 \mathrm{~mm}$, it is considered very sensitive and extremely sensitive for all diameters greater than $20 \mathrm{~mm}$ [22].

In addition, the antibiotics used are shown to be very sensitive to all the tested bacterial strains compared to DA. However, DA has signed a better activity on Pseudomonas aeruginosa; and the determination of the antibacterial parameters indicated that DA has bactericidal activities upon all the tested strains. According to the reported findings of Fauchere (2002); when the ratio MBC/MIC = 1, the extract is called "absolute bactericidal", if $\mathrm{MBC} / \mathrm{MIC}<2$, the extract is "bactericidal", and when MBC/MIC >2, the extract is simply called "bacteriostatic" [23].

It appears from our study that the decoction of Lannea barteri Engl. has an antibacterial potential at $100 \mathrm{mg} / \mathrm{ml}$ on the strains of Pseudomonas aeruginosa and Acinetobacter baumannii. This activity could be related to the presence of sterols, terpenes, coumarins, flavonoids, tannins, and alkaloids found in the tested extracts [14]. Thus, Lannea barteri Engl. could be used to reduce some nosocomial infections and especially urinary infections in hospitals.

\section{CONCLUSION}

This study is a scientific contribution for a better understanding of the chemical composition and biological potentials of Lannea barteri Engl. (DA), a plant used in traditional medicine to treat urinary tract infections. From our findings, the chemical investigation conducted on the aqueous decoction of DA has highlighted the presence of many phytocompounds; such as sterols, terpenes, coumarins, flavonoids, tannins and alkaloids with predominance in phenolic compounds $(0.757 \pm 0.03 \mathrm{mg} \mathrm{AG} / \mathrm{g} \mathrm{DM})$ and particularly flavonoids $(0.23 \pm 0.01 \mathrm{mg}$ AG/g DM). Moreover, the study of the antibacterial potential has revealed an absolute bactericidal character of Lannea barteri Engl. on Pseudomonas aeruginosa and Acinetobacter Baumannii. These bactericidal activities are potentially due to the richness of the plant in various phytochemical compounds as described in this work. Thus, the traditional use of Lannea barteri Engl. against urinary infections seems to be justified based on our scientific results.

Further useful chemical researches are planned for the isolation of valuable active ingredients and new pharmacophores that could be used against some nosocomial infections.

\section{AUTHORS CONTRIBUTIONS}

All the author have contributed equally

\section{CONFLICT OF INTERESTS}

Authors have equal contribution in this work and declare no conflict of interests.

\section{REFERENCES}

1. Danny KK, Prosper KM, Baudouin B, Michele DW. Etude de la prevalence des infections nosocomiales et des facteurs associes dans les deux hopitaux universitaires de Lubumbashi, Republique Democratique du Congo: cas des Cliniques Universitaires de Lubumbashi et l'Hôpital Janson Sendwe. Afr Med J 2016;24:275-626.

2. Van Looveren M, Goossens H. Antimicrobial resistance of Acinetobacter spp. in Europe. Clin Microbiol Infect 2004;10:684-704.

3. Dijkshoorn L, Aucken H, Gerner-Smidt P. Comparison of outbreak and non-outbreak Acinetobacter baumannii strains by genotypic and phenotypic methods. J Clin Microbiol 1996;34:1519-25.

4. Enquete nationale de prevalence des infections nosocomiales 2006. Resultats préliminaires au 12/01/2007. Institut de veille sanitaire (InVS); 2007.

5. Auajjar N, Attarass IB, ElhalouI NE, Badoc A. Multiresistance aux antibiotiques de Pseudomonas Aeruginosa, P. fluorescens et Staphylococcus aureus et survie sur divers tissus hospitaliers. Bull Soc Pharm Bordeaux 2006;145:61-76.

6. Mansour W, Bouallegue O, Jeday S, Naija W, Boujaafar N. Caracterisation clinico-epidemiologique des infections a Acinetobacter baumannii resistant a limipeneme au CHU sahloul (Tunisie). Ann Biol Clin 2007;65:593-9.

7. Kone WM, Soro D, Dro B, Yao K, Kamanzi K. Chemical composition, antioxidant, antimicrobial and acetyl cholinesterase inhibitory properties of Lannea Barteri (Anacardiaceae). Aust J Basic Appl Sci 2011;5:1516-23.

8. Ladiguina EY, Safronitch LN, Otriachenkova VE, Balandina IA, Grinkevitch. Analyse chimique des plantes médicinales. Edition Moskva, Vischaya Chkola; 1983. p. 347.

9. Bekro YA, Mamyrbekova Bekro J, Boua B, Tra Bi F, Ehile E. Etude ethnobotanique et screening phytochimique de Caesalpinia benthamiana (Baill.) Herend et Zarucchi (Caesalpiniaceae). Sci Nat 2007;4:217-25.

10. Kabran GR. Etude chimique et cytotoxique de dix plantes de cote d'Ivoire, utilisees dans le traitement traditionnel du cancer de sein. Thèse unique de doctorat, Universite $d$ abobo-adjame Cote d'Ivoire; 2011. p. 265.

11. Boua BB, Bekro YA, Mamyrbekova Bekro J. Phytocompounds of the extracts of four medicinal plants of Côte d'Ivoire and assessment of their potential antioxidant by thin Layer Chromatography. Eur J Sci Res 2008;24:219-28.

12. Akers MJ. Parenteral quality control: sterility, pyrogen, particulate, and package integrity testing. marcel dekker Inc., New York; 1985. p. 253.

13. Carroll KC, Weinstein MP. Manual and automated systems for detection and identification of microorganisms. In: Murray PR. Manual of clinical microbiology. 9th ed. Vol. 1. American Society for Microbiology Press: Washington; 2007. p. 192-217.

14. Konan KF. Activite antibacterienne sur les enterobactéries productrices de beta-lactamases a spectre elargi, et potentiel antioxydant in vitro de Terminalia glaucescens planch ex benth. (Combretaceae), une plante médicinale ouest-africaine. Thèse de doctorat, Université d Abidjan (Côte d'Ivoire); 2015. p. 183.

15. Kone WM, Kamanzi AK, Terreaux C, Hostettmann K, Traore D, Dosso M. Traditional medicine in North cote d'Ivoire: screening of 50 medicinal plants for antibacterial activity. J Ethnopharmacol 2004;93:43-9.

16. Dosso M, Faye Kette H. Controle de qualite de lantibiogramme en pratique courante: experience du laboratoire de bacteriologie de IInstitut pasteur de cote d'ivoire. Bacteriologie int $n{ }^{\circ}$ spécial; 2000. p. 53.

17. Lagnika L. Etude photochimique et activité biologique de substances naturelles isolées de plantes béninoises. Thèse de doctorat, Université Louis Pasteur (Strasbourg, France); 2005. p. 268.

18. Benkiki N. Etude phytochimique des plantes médicinales algériennes: Ruta Montana, Matricaria pubescens et Hypericum 
perfoliatum. These de Doctorat detat, Departement de chimie, Universite El-Hadj Lakhdar Batna Algerie; 2006. p. 198.

19. Mamyrbekova Bekro JA, Konan KM, Bekro YA, Djie Bi MG, Zom Bi TJ, Mambo V, et al. Phytocompounds of the extracts of four medicinal plants of Côte d'Ivoire and assessment of their potential antioxidant by thin layer chromatography. Eur J Sci Res 2008;24:219-28.

20. Konan KM. Etude chimique et évaluation de l'activite antioxydante de quatre Plantes medicinales de cote d'Ivoire.
These unique de doctorat, Universite d'Abobo-Adjame Côte d'Ivoire; 2010. p. 112.

21. Biyiti LF, Meko'o DJL. Recherche de l'activité antibactérienne de quatre plantes médicinales camerounaises. Pharm Med Trad Afr 2004;13:11-20.

22. Ponce AG, Fritz R, Del Alle C, Roura SI. Antimicrobial activity of essential oil on the native micro flora of organic swiss chard Lebensmittel Wissenschaft und Technologic 2003;36:679-84.

23. Fauchere IL, Avril JL. Bacteriologie generale et medicale. Ed ellipses Paris; 2002. 